\title{
KYIV MONITORING PROGRAM OF FRAUNHOFER LINES VARIATION WITH 11-YEAR CYCLE OF SOLAR ACTIVITY
}

\author{
S. N. Osipov, R. I. Kostik, N. G. Shchukina \\ Main Astronomical Observatory, NAS of Ukraine, \\ 27, Academika Zabolotnoho St., Kyiv, UA-03143, Ukraine \\ osipov@mao.kiev.ua,kostik@mao.kiev.ua,shchukin@mao.kiev.ua \\ (Received March 17, 2017; received in final form - June 01, 2017)
}

\begin{abstract}
The monitoring program of long-term variation of selected Fraunhofer lines is described. The aim of the program is to study how the physical parameters of the quiet solar atmosphere change over the solar cycle No. 24. The research is based on high spectral resolution observations of the quiet Sun using the horizontal solar telescope ATSU-5 of the Main Astronomical Observatory of the National Academy of Sciences of Ukraine. The diagnostics of the solar cycle atmospheric variation includes observations of the $\mathrm{H} \alpha$, Ca II $\mathrm{K} \& \mathrm{H}$ and about 40 spectral lines of neutral and ionized chemical elements at different positions on the solar disk. Since 2012 the observations are performed daily, when the weather conditions allow. The observational season lasts from March to October. The first results of the observations show that the line core depths and full widths at half maximum of the weak Fe I $538.634 \mathrm{~nm}$, moderate Fe I $539.829 \mathrm{~nm}$, and strong Fe I $558.677 \mathrm{~nm}$ lines, as well as the bisector curvature of the last two lines show response to the cycle modulation of the total unsigned magnetic field of the Sun. The behavior of these line parameters can be explained by variations of the temperature and convective motions of the quiet photosphere during this cycle.

Key words: solar instrumentation, observations, spectral lines, solar magnetic field, solar cycle variations.
\end{abstract}

PACS number(s): 95.55.Qf, 95.75.-z, 95.75.Fg, 95.85.Kr, 96.60.Mz, 96.50.Wx

\section{INTRODUCTION}

The first monitoring programs aimed to study longterm changes in the Fraunhofer spectrum of the Sun started in the mid-fifties of the last century. An overview of some of them can be found in the monograph by Atroshchenko et al. [1]. Many of these programs are usually based on the observations whose duration does not exceed one or two years (see, e.g., [2] and references therein). As an exception, there are several programs of long-term monitoring of Fraunhofer lines in the solar spectrum. In 1984 Krat and Kokhan [3] published results of 11-year center-to-limb observations of selected Fraunhofer lines carried out since 1969. They found some changes in the parameters of some lines with a cycle of solar activity. Doyle et al. [4] studied the changes of Mn I $539.5 \mathrm{~nm}$ and Ca II H $393.3 \mathrm{~nm}$ lines in the solar flux spectrum (i.e., "the Sun as a star") recorded during 1978-1993. Around 35 years Livingston et al. [5-7] observed chromospheric (H $\alpha$, Ca II K \& H, CN 388.3 nm, Ca I $854.2 \mathrm{~nm}$, He I $1083 \mathrm{~nm}$ ) and photospheric (Fe I $537.9579 \mathrm{~nm}$, C I $538.0323 \mathrm{~nm}$, and Ti II $538.1026 \mathrm{~nm}$ ) Fraunhofer lines, integrated over the full disk and some of them for a small region near the center of the solar disk. After 2006 SOLIS (Synoptic Optical Long-term Investigations of the Sun) provides autonomous full-disk spectral, magnetic, and imaging measurements to help understanding solar activity and its effect on the Earth's climate and atmosphere $[8,9]$. It should be noted that the Sun as a star monitoring of spectral lines reflects variations of solar activity and makes it impossible to study separately the cycle variations of the quiet Sun. In spite of the considerable efforts of many researchers it is still unknown how the physical parameters of the quiet solar atmosphere change over the 11-year cycle of solar activity. Our long-term monitoring program of selected Fraunhofer lines aims to clarify this question.

\section{OBSERVATIONS}

Our research is based on center-to-limb observations of the quiet Sun obtained with a high $(\mathrm{R}=330000)$ spectral resolution at the horizontal solar telescope ATSU-5 of the Main Astronomical Observatory of the National Academy of Sciences of Ukraine (hereinafter MAO NASU). The telescope described by Gurtovenko, Kostik and Shchukina $[10,11]$ was set into operation in 1966. In 2011 its reconstruction was performed. The main telescope characteristics are: a $440 \mathrm{~mm}$ coelostat and additional mirrors, a 440-mm main mirror with a focal length of $17.5 \mathrm{~m}$. The telescope has a spectrograph which can be used both in one and double pass mode. The spectrograph collimator and camera $500-\mathrm{mm}$ mirror is built from a single block of glass and has a focal length of $7 \mathrm{~m}$. Currently, the telescope is equipped with a CCD camera SBIG ST-8300M. Its array $(17.96 \times 13.52 \mathrm{~mm})$ has $3326 \times 2504$ pixels at 5.4 microns. The grating has a ruled area of $140 \times 150 \mathrm{~mm}$ with 600 lines per $\mathrm{mm}$. The instrumental profile of the spectrograph in the fourth order measured at $632.8 \mathrm{~nm}$ using a helium-neon laser has a half width of $18-20 \mathrm{~m} \AA$. The monitoring of the instrumental profile during the observational season shows the variation of its half-widths within $10 \%$. More details on 


\section{S. N. OSIPOV, R. I. KOSTIK, N. G. SHCHUKINA}

the instrumental profile measurements are described by Osipov in his paper [12].

The diagnostics of the solar cycle variation of the quiet solar atmosphere includes observations of the $\mathrm{H} \alpha$, Ca II K\&H and about 40 spectral lines of neutral and ionized chemical elements (CI, CaI, CrI, MnI, Fe I, FeII, TiII) in nine spectral regions from $393 \mathrm{~nm}$ to $657 \mathrm{~nm}$ (393.0-393.7, 524.4-525.2, 532.0-532.8, 537.6$538.5, \quad 539.0-539.8, \quad 558.4-559.2, \quad 624.9-625.7,632.6-$ $633.3,655.3-657.3 \mathrm{~nm})$. The formation heights of these lines cover the large portion of the photosphere, the temperature minimum and the lower chromosphere. Since 2012 we perform observations at three positions on the solar disk (center, north and south poles) with the entrance slit height of 2 arc min. The exposure time is as a rule in the range of $1-2.5 \mathrm{~s}$.
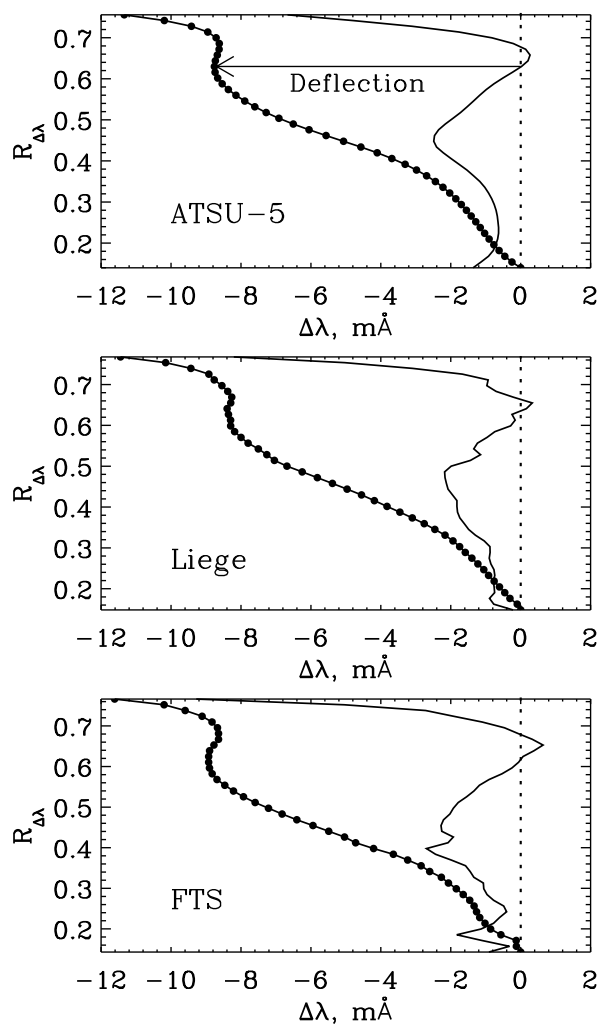

Fig. 1. Disk-center bisector $V\left(R_{\Delta \lambda}\right)$ (open circles with solid line) of the Fe I $532.41 \mathrm{~nm}$ line and curve $d V / d R(\Delta \lambda)$ (solid line) that demonstrates bisector noise. Top panel: observations at ATSU-5. Middle panel: Liège atlas [13]. Bottom panel: FTS atlas $[14,15]$.

The observing program consists in using the spectrograph in one pass mode. Figure 1 quantifies the quality of the observations at the telescope ATSU-5 of the MAO NASU. The top, middle and bottom panels of the figure present disk-center bisectors $V\left(R_{\Delta \lambda}\right)$ and bisector noise $d V / d(\Delta \lambda)$ of the Fe I $532.4 \mathrm{~nm}$ line profile obtained from observations at ATSU-5, from Liège [13] and FTS [14,15] atlases, respectively. We define bisector $V\left(R_{\Delta \lambda}\right)$ as the loci of points midway between equal-intensity points on either side of the line profiles:

$$
V\left(R_{\Delta \lambda}\right)=\left(\Delta \lambda_{b}+\Delta \lambda_{r}\right) / 2,
$$

where $\Delta \lambda_{b}$ and $\Delta \lambda_{r}$ are, respectively, the wavelengths of the blue and red line wings for a given value of the line residual intensity $R_{\Delta \lambda}$. Figure 1 clearly shows that compared to the double pass mode, such a scheme makes it possible to measure line bisectors with an accuracy higher than that of Liège and FTS atlases. In addition, it enables to make faster observations reducing seeing effects.

We developed the methods to account for the turbulence inside the telescope ATSU-5, the instrumental scattered light and instrumental profile of its spectrograph. This allows to record the Fraunhofer lines on long time scales with a high precision metrological stability. The observations are performed daily, when the weather conditions allow. Observational season lasts from March to October. In total we have 284 days of observations between 2012 and 2016.

\section{FIRST RESULTS}

We show preliminary results of our monitoring program using observations of three Fe I lines of different strength at the solar disk center. The first Fe I 538.634 $\mathrm{nm}$ line is rather weak. According to Gurtovenko and Kostik [10] its formation region extends from the bottom of the photosphere (the wings) to the height of $H_{\mathrm{D}}=178 \mathrm{~km}$ (the line core). The second Fe I $539.829 \mathrm{~nm}$ line is a typical representative of moderate Fe I lines. It is formed in the layer between the lower and middle photosphere $\left(H_{\mathrm{D}}=315 \mathrm{~km}\right)$. The third line is Fe I 558.677 nm. As shown by Shchukina and Trujillo Bueno [16] the formation region of this strong line covers the whole photosphere, herewith its core intensity comes from the temperature minimum.

In the present work, we analyze three parameters of these lines. They are a line core depth (D), full width at half maximum (FWHM) and a line asymmetry. The first two of them can be indicators of the temperature variation of the solar atmosphere, while the third one can be used as a diagnostic tool to investigate the variation of solar granulation and convective motions. In this study, we use for description of the line asymmetry the bisector curvature or, in other words, its deflection. We measure this deflection at the wavelength point where its derivative becomes zero (see Fig. 1). At disk center, bisectors for stronger lines are generally convex toward the blue wavelength side, a curve reminiscent of the letter "C", while the bisectors of weaker lines look like an inclined curve. It means that for weak lines like Fe I $538.634 \mathrm{~nm}$ we cannot measure the bisector deflection. 

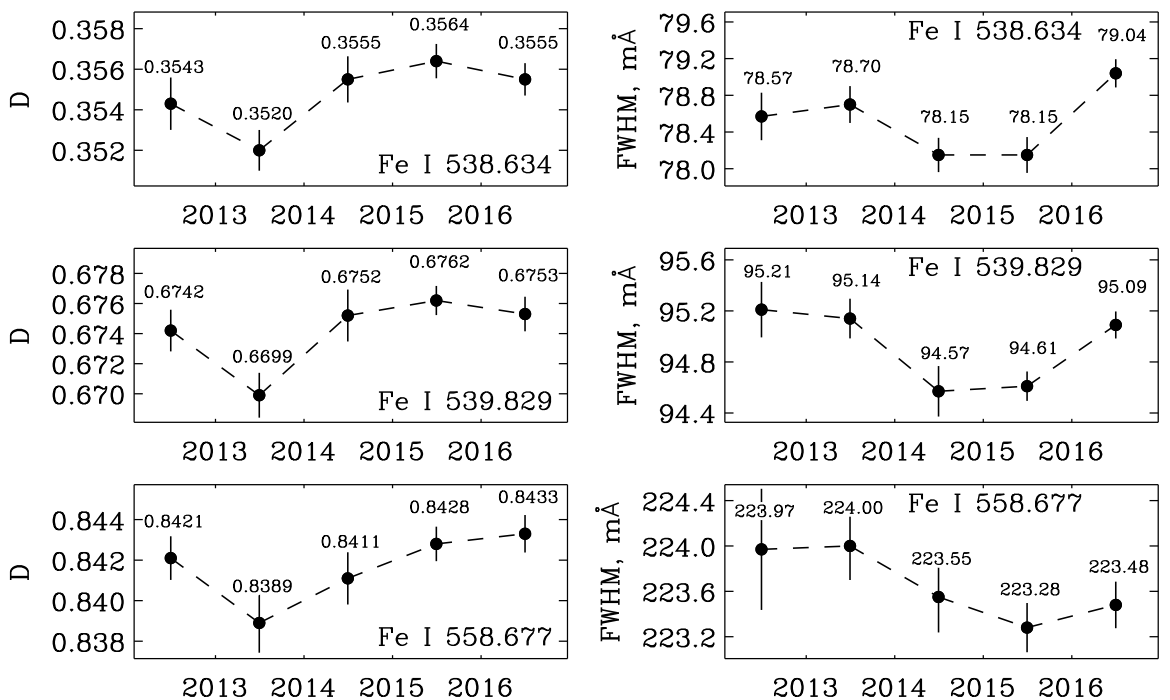

Fig. 2. Variations of the line core depth (left panels) and the line full width at half maximum (right panels) of the three Fe I lines obtained at ATSU-5 telescope over observing seasons of 2012-2016.

Figure 2 shows variations with time of the line core depth and full width at half maximum of these lines obtained for the quiet regions of the solar disk center during observations at the ATSU-5 telescope. Time variations of the bisector curvature of the moderate Fe I $539.829 \mathrm{~nm}$ and the strong Fe I $558.677 \mathrm{~nm}$ lines are shown on Fig. 3. In these figures black filled circles represent values averaged over the observing seasons of 2012-2016, while the vertical lines are $95 \%$ confidence intervals for random errors. As one can see, the line parameter variations are small. For the line depth they are within a few tenths of a percent. The amplitudes of the FWHM variations are below $1 \mathrm{~m} \AA$ and variations of the bisector curvature are less than $10 \mathrm{~m} / \mathrm{s}$.

We compared these variations with the global unsigned magnetic field of the Sun measured by the Wilcox Solar Observatory [17] over the years 2012-2016 (see Fig. 4). The first two white points shown on Fig. 4 are close to the first maximum of the 24th cycle of solar activity. Next two white points present the peak of the activity observed in 2014 and 2015. The last point is on the descending part of the cycle. Our measurements reveal that the line core depths D (Fig. 2, left panel) and FWHM (Fig. 2, middle panel) of all three Fe I lines and the bisector curvature (Fig. 3) of the stronger Fe I lines track the variations of the total unsigned magnetic flux. Interestingly, their line depths increase with the total unsigned magnetic flux, while their full widths FWHM become narrower as we approach the peak of the solar activity. At the same time, we found that the equivalent widths $W$ of these lines do not correlate with the solar activity cycle. Their variations are below $1 \mathrm{~m} \AA$. The behavior of the $\mathrm{D}$ and FWHM parameters can be explained by assuming that near the maximum of the 11-year solar activity the temperature gradient of the quiet photosphere becomes slightly larger. Consequently, the line wing and core intensities decrease and the Fe I lines become deeper and narrower. An observable change of the line bisector curvature might mean that the convection in the Sun can be modulated by magnetic field variations affecting the energy transport in the outer solar layers.
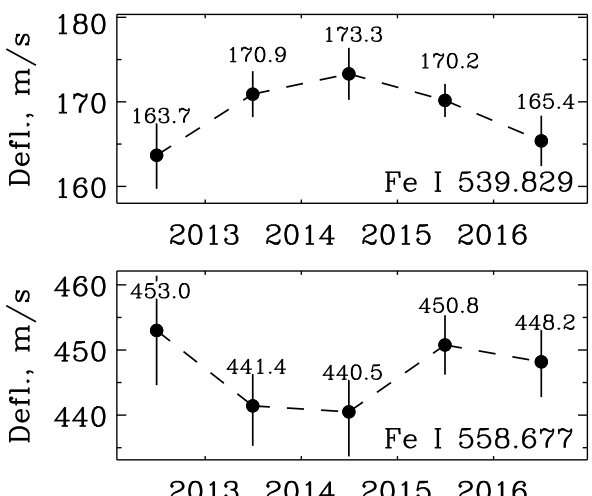

Fig. 3. Variations of the line bisector curvature (deflection), measured in the velocity units for the moderate and strong Fe I lines obtained at ATSU-5 telescope over observing seasons of 2012-2016.

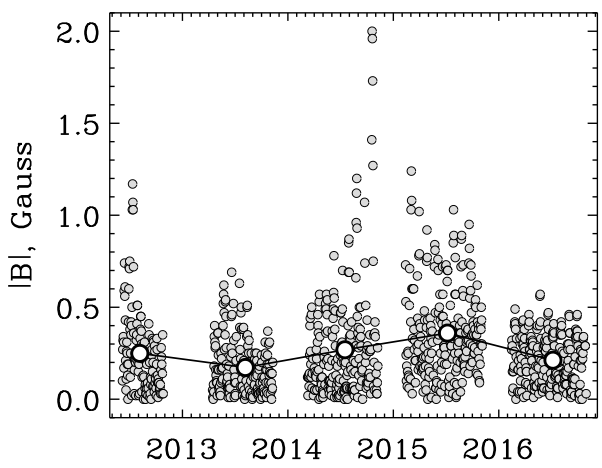

Fig. 4. The total unsigned magnetic field of the Sun in Gauss as measured by the Wilcox Solar Observatory [17] over 2012-2016. Grey circles indicate the value of the magnetic field for observing days at the ATSU-5. White circles are averaged over each period. 


\title{
S. N. OSIPOV, R. I. KOSTIK, N. G. SHCHUKINA
}

\section{COCLUSIONS}

The high precision metrological stability on long time scales of the telescope ATSU-5 of the MAO NASU allows to measure the slightest temporal changes of the solar spectral line parameters. Thanks to this, we were able to detect that during 2012-2016 the line parameters of the three Fe I lines correlated with the variation of the global unsight magnetic field of the Sun. We interpreted this result as an indication that the quiet solar atmosphere may be affected by the cycle magnetism. In order to prove or refute this conclusion we continue our monitoring program and diagnostics of the solar cycle variation of the quiet atmosphere resorting to observations not only of these three Fe I lines but all selected Fraunhofer lines counting over 40.
We are also going to compare the observed long-term behavior of the Fraunhofer lines with predictions of 3D magnetohydrodynamics simulations of solar convection. We hope, this should quantify the temperature and convective variations of the quiet solar photosphere over the 11-year cycle of solar activity. We are planning to present the results of such a comparison in future publications.

\section{ACKNOWLEDGMENTS}

The authors are very grateful to Volodymyr Bezpal'ko for a technical maintenance of the observations. Comprehensive support of the monitoring program by academician Yaroslav Yatskiv is gratefully acknowledged.
[1] I. N. Atroshchenko et al., Variations of the global characteristics of the Sun (Naukova Dumka, Kiev, 1991).

[2] F. Cavallini, G. Cepatelli, A. Righini, Astron. Astrophys. 158, 275 (1986).

[3] V. A. Krat, E.K. Kokhan, Pulkovo, Glavnaia Astronomicheskaia Observatoriia, Izvestiia (Transactions of the Main Astronomcal Observatory at Pulkovo), no. 202, 49 (1984).

[4] J. G. Doyle, D. Jevremovi, C. I. Short, P. H. Hauschildt, W. Livingston, I. Vince, Astron. Astrophys. 369, L13 (2001).

[5] W. Livingston, H. Holweger, Astrophys. J. 252, 375 (1982).

[6] W. Livingston, L. Wallace, O. R. White, M. S. Giampapa, Astrophys. J. 657, 1137 (2007).

[7] W. Livingston, O. R. White, L. Wallace, J. Harvey, Mem. S. A. It. 81, 643 (2010).

[8] C. U Keller, J. W. Harvey, M. S. Giampapa, in Innovate Telescopes and Instrumentation for Solar Astrophysics, edited by S. L. Keil, S. V. L. Avakyan, Proc. SPIE 4853, 154 (2003).

[9] http://solis.nso.edu/0/index.html

[10] E. A. Gurtovenko, R. I. Kostik, Fraunhofer Spectrum and the System of Solar Oscillator Strengths (Naukova Dumka, Kiev, 1989).

[11] R.I. Kostik, N. G. Shchukina, in Advances in Physics of Sunspots, eds. B. Schmieder, J.C. del Toro Iniesta, M. Vazquéz, ASP Conf. Ser. 118, 372 (1997).

[12] S. N. Osipov, Kinem. Phys. Celest. Bodies, 31, 261, (2015).

[13] L. Delbouille, G. Roland, L. Neven, Photometric Atlas of the Solar Spectrum from $\lambda 3000$ to $\lambda 10000$ A (Liège: Institut d'Astrophysique de l'Université de Liège, 1973).

[14] H. Neckel, D. Labs, Solar Phys. 90, 205 (1984).

[15] H. Neckel, Solar Phys. 184, 421 (1999).

[16] N. Shchukina, J. Trujillo Bueno, Astrophys. J. 550, 970 (2001).

[17] http://wso.stanford.edu/meanfld/.

\section{КИЇВСЬКА ПРОГРАМА МОНІТОРИНГУ ВАРІАЦІЙ ФРАУНГОФЕРОВИХ ЛІНІЙ З 11-РІЧНИМ ЦИКЛОМ СОНЯЧНОї АКТИВНОСТІ}

\author{
С. М. Осіпов, Р. І. Костик, Н. Г. Щукіна \\ Головна астрономічна обсерваторя НАН України, \\ вул. Акад. Заболотного, 27, Київ, 03143, Україна, \\ e-mail:osipov@mao.kiev.ua,kostik@mao.kiev.ua,shchukin@mao.kiev.ua
}

\begin{abstract}
Описано програму моніторингу довгострокових змін фраунгоферових ліній у сонячному спектрі. Мета програми - з'ясувати поведінку змін фізичних параметрів спокійної сонячної атмосфери протягом 24-го циклу сонячної активності. Дослідження базуються на спостереженнях із високою спектральною роздільною здатністю, проведених на горизонтальному сонячному телескопі Головної астрономічної обсерваторії Національної академії наук України. Для діагностики варіацій спокійної атмосфери Сонця з 24-м циклом використано спостереження ліній $\mathrm{H} \alpha$, Са II K \& H і більш ніж 40 ліній нейтральних та йонізованих хімічних елементів у спокійних ділянках центру сонячного диска. Починаючи від 2012 року спостереження проводять з березня до жовтня щодня, коли дозволяють погодні умови. Перші результати спостережень указують на те, що глибина і напівширина слабкої Fе г 538.634 нм, помірної Fе I 539.829 нм і сильної Fе г 558.677 нм ліній, а також прогин бісектора останніх двох ліній реагують на модуляції з 11-річним циклом сонячної активності загального магнітного поля Сонця. Поведінку зазначених параметрів ліній можна пояснити варіаціями температури й конвективних параметрів спокійної фотосфери протягом цього циклу.
\end{abstract}

